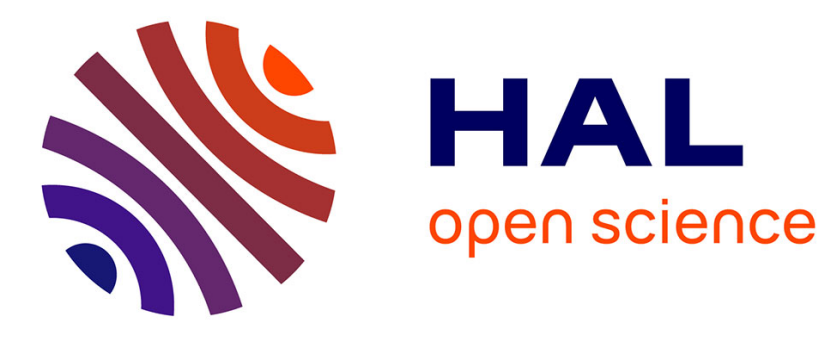

\title{
Antiprotozoal activity of Melampyrum arvense and its metabolites
}

\author{
Hasan Kirmizibekmez, Irem Atay, Marcel Kaiser, Reto Brun, Michelle \\ Cartagena, Néstor Carballeira, Erdem Yesilada, Deniz Tasdemir
}

\section{- To cite this version:}

Hasan Kirmizibekmez, Irem Atay, Marcel Kaiser, Reto Brun, Michelle Cartagena, et al.. Antiprotozoal activity of Melampyrum arvense and its metabolites. Phytotherapy Research, 2010, 25 (1), pp.142. 10.1002/ptr.3233 . hal-00599832

\section{HAL Id: hal-00599832 \\ https://hal.science/hal-00599832}

Submitted on 11 Jun 2011

HAL is a multi-disciplinary open access archive for the deposit and dissemination of scientific research documents, whether they are published or not. The documents may come from teaching and research institutions in France or abroad, or from public or private research centers.
L'archive ouverte pluridisciplinaire HAL, est destinée au dépôt et à la diffusion de documents scientifiques de niveau recherche, publiés ou non, émanant des établissements d'enseignement et de recherche français ou étrangers, des laboratoires publics ou privés. 


\section{Antiprotozoal activity of Melampyrum arvense and its metabolites}

\begin{tabular}{|r|l|}
\hline Journal: & Phytotherapy Research \\
\hline Manuscript ID: & PTR-10-0093.R2 \\
\hline Wiley - Manuscript type: & Short Communication \\
\hline Dathor: & 23-Apr-2010 \\
\hline Complete List of Authors: & $\begin{array}{l}\text { Kirmizibekmez, Hasan; Yeditepe University, Faculty of Pharmacy, } \\
\text { Department of Pharmacognosy } \\
\text { Atay, Irem; Yeditepe University, Faculty of Pharmacy,, Department } \\
\text { of Pharmacognosy } \\
\text { Kaiser, Marcel; Swiss Tropical Institute, Department of Medical } \\
\text { Parasitology and Infection Biology } \\
\text { Brun, Reto; Swiss Tropical Institute, Department of Medical } \\
\text { Parasitology and Infection Biology } \\
\text { Cartagena, Michelle; University of Puerto Rico, Faculty of Natural } \\
\text { Sciences, Department of Chemistry } \\
\text { Carballeira, Néstor; University of Puerto Rico, Faculty of Natural } \\
\text { Sciences, Department of Chemistry } \\
\text { Yesilada, Erdem; Yeditepe University, Faculty of Pharmacy ,' } \\
\text { Department of Pharmacognosy } \\
\text { Tasdemir, Deniz; University of London, School of Pharmacy, Centre } \\
\text { for Pharmacognosy and Phytotherapy }\end{array}$ \\
\hline \hline Keyword: & $\begin{array}{l}\text { Melampyrum arvense, iridoid glucosides, flavonoids, Trypanosoma, } \\
\text { Leishmania, Plasmodium }\end{array}$ \\
\hline \hline
\end{tabular}

\section{scholarONE" \\ Manuscript Central}




\title{
Antiprotozoal activity of Melampyrum arvense and its metabolites
}

\author{
Hasan Kirmizibekmez ${ }^{1}$, Irem Atay ${ }^{1}$, Marcel Kaiser ${ }^{2}$, Reto Brun ${ }^{2}$, Michelle M. \\ Cartagena $^{3}$, Néstor M. Carballeira ${ }^{3}$, Erdem Yesilada ${ }^{1}$ and Deniz Tasdemir ${ }^{4, *}$ \\ ${ }^{1}$ Department of Pharmacognosy, Faculty of Pharmacy, University of Yeditepe, 34755 \\ Kayisdagi, Istanbul, Turkey \\ ${ }^{2}$ Department of Medical Parasitology and Infection Biology, Swiss Tropical Institute, \\ 4002 Basel, Switzerland \\ ${ }^{3}$ Department of Chemistry, University of Puerto Rico, Faculty of Natural Sciences, PO \\ Box 70377, San Juan, Puerto Rico 00936-8377, United States of America \\ ${ }^{4}$ Centre for Pharmacognosy and Phytotherapy, School of Pharmacy, University of \\ London, London WC1N 1AX, United Kingdom
}

Running head: Antiprotozoal compounds of Melampyrum arvense

\section{Correspondence}

Dr. Deniz Tasdemir

Centre for Pharmacognosy and Phytotherapy, School of Pharmacy

University of London

29-39 Brunswick Square, London WC1N 1AX, United Kingdom

Phone: +44-20-7753 5845

Fax: +44-20-7753 5909

E-mail: deniz.tasdemir@pharmacy.ac.uk 


\begin{abstract}
An activity guided isolation of the $\mathrm{H}_{2} \mathrm{O}$ subextract of the crude extract of Melampyrum arvense L. afforded iridoid glucosides aucubin (1), melampyroside (2), mussaenoside (3), mussaenosidic acid (4), 8-epi-loganin (5); flavonoids, apigenin (6), luteolin (7), luteolin 7-O- $\beta$-glucopyranoside (8); a lignan glycoside dehydrodiconiferyl alcohol 9-O$\beta$-glucopyranoside (9); and benzoic acid (10). $\beta$-Sitosterol (11) and a fatty acid mixture (12) were identified as the active principles of the $\mathrm{CHCl}_{3}$ subextract. The structures of the isolates were elucidated by spectroscopic methods, while the composition of $\mathbf{1 2}$ was identified by GC-MS after methylation. Luteolin (7) appeared as the most active compound against Trypanosoma brucei rhodesiense and Leishmania donovani $\left(\mathrm{IC}_{50}\right.$ values 3.8 and $3.0 \mu \mathrm{g} / \mathrm{ml}$ ). Luteolin $7-O$ - $\beta$-glucopyranoside (8) displayed the best antiplasmodial activity against Plasmodium falciparum ( $\mathrm{IC}_{50}$ value $2.9 \mu \mathrm{g} / \mathrm{ml}$ ). This is the first detailed phytochemical study on Turkish $M$. arvense and the first report of the antiprotozoal effect of Melampyrum species and its constituents.
\end{abstract}

Keywords: Melampyrum arvense; iridoid glucosides; flavonoids; Trypanosoma; Leishmania; Plasmodium. 


\section{INTRODUCTION}

An estimated one billion people - one seventh of the world's population - are infected with one or more neglected tropical diseases (WHO, 2006). There are an estimated 70 million people in 16 countries in sub-Saharan Africa who suffer from Human African trypanosomiasis (sleeping sickness). One of the two forms of Trypanosoma, T. brucei rhodesiense, is responsible for this acute illness usually occurring in residents of eastern and southern Africa. The WHO estimates that American trypanosomiasis (Chagas disease), which is caused by $T$. cruzi, affects about 20 million people, and causes 45.000-70.000 deaths in South America annually (Bonomo and Salata, 2007). Leishmaniasis currently threatens approximately 350 million people in 88 countries around the world, with about 2 million affected annually (Mishra et al., 2009). Leishmania donovani is the causative agent of visceral leishmaniasis (Kala-azar), which is considered as the most severe form of leishmaniasis (Rocha et al., 2005). Plasmodium falciparum is the predominant species causing malaria in Africa, Haiti, New Guinea, Southeast Asia, South America and Oceania (Krause, 2007), and kills over one million people annually (WHO, 2006). Current chemotherapeutics for these diseases have some drawbacks such as serious adverse effects, requirement of long treatment regimes as well as the emergence of drug resistant parasites. Thus, discovery of new, safe and effective antiprotozoal drugs is becoming a pressing need.

The genus Melampyrum (formerly Scrophulariaceae sensu lato, now Orobanchaceae) consists of annual semi-parasitic plants and is represented by two species, M. arvense and M. pratense in the flora of Turkey (Hedge, 1978). Iridoid glucosides were reported to be the chief chemical constitutes of $M$. arvense. (Damtoft 
et al., 1984) Recent studies have revealed antioxidant (Stajner et al., 2009) and protein kinase C inhibitory (Galkin et al., 2009) effects of $M$. barbatum and $M$. pratense. There is however no report on antiprotozoal effect of any member of the Melampyrum genus. In the continuation of our efforts to find natural antiprotozoal lead compounds from Turkish plants (Kirmizibekmez et al., 2004; Tasdemir et al., 2005) we now report in vitro antimalarial, trypanocidal, leishmanicidal and cytotoxic activities of the crude methanolic extract and its subextracts of $M$. arvense, as well as the constituents of those extracts.

\section{MATERIAL AND METHODS}

General experimental procedures. NMR spectra were recorded on a Bruker AVANCE $500 \mathrm{MHz}$ spectrometer. Chemical shift values $(\delta)$ were reported in parts per million (ppm) relative to appropriate internal solvent standard, and coupling constants ( $J$ values) are given in hertz $(\mathrm{Hz})$. Nano-electrospray mass spectrometry (nano-ES-MS) analyses were performed on a $\mathrm{LCQ}^{\mathrm{duo}}$, ion trap instrument (Thermo Fisher Scientific, San Jose, CA, USA) fitted with a nano-electrospray ionisation (nano-ES) source. TLC analyses were carried out on silica gel $60 \mathrm{~F}_{254}$ precoated plates (Merck, Darmstadt), detection by $1 \%$ vanillin/ $\mathrm{H}_{2} \mathrm{SO}_{4}$. For medium-pressure liquid chromatographic (MPLC) separations, Combi Flash Companion (Isco), were used with Redi step columns packed with LiChroprep $\mathrm{C}_{18}$ (130 g and $43 \mathrm{~g}$, Teledyne Isco). Silica gel 60 (0.063-0.200 mm; Merck, Darmstadt), polyamide (Fluka) and Sephadex LH-20 (Fluka) were utilized for open column chromatography (CC). All solvents were HPLC quality. 
Plant material. The aerial parts of $M$. arvense L. were collected from Kastamonu, Turkey in 2007. The plant material was identified by Dr. Galip Akaydin. The voucher specimens (Akaydin 11546) of this plant were deposited at the Herbarium of the Faculty of Education, Hacettepe University, Ankara, Turkey.

Extraction and isolation. The air-dried and powdered aerial parts of $M$. arvense (110 g) were extracted twice with $\mathrm{MeOH}(600 \mathrm{ml})$ at $45{ }^{\circ} \mathrm{C}$ for $4 \mathrm{~h}$. The combined methanolic extracts were evaporated to a residue (13.9 g; yield $12.6 \%)$. The extract was suspended in $\mathrm{H}_{2} \mathrm{O}(25 \mathrm{ml})$, and extracted with equal volumes of $\mathrm{CHCl}_{3}(25 \mathrm{ml} \times 6)$. The $\mathrm{H}_{2} \mathrm{O}$-soluble portion ( $8 \mathrm{~g}$ ) was loaded onto a polyamide ( $40 \mathrm{~g}$ ) column eluting with $\mathrm{H}_{2} \mathrm{O}$ (200 mL) and a stepwise gradient of $\mathrm{MeOH}$ in $\mathrm{H}_{2} \mathrm{O}(10-100 \%$ in steps of $10 \%$, each 100 $\mathrm{mL})$ to yield nine fractions, A-I. Fraction $\mathrm{B}(4.5 \mathrm{~g})$ was subjected to a $\mathrm{SiO}_{2} \quad(140 \mathrm{~g})$ column using $\mathrm{CH}_{2} \mathrm{Cl}_{2}-\mathrm{MeOH}-\mathrm{H}_{2} \mathrm{O}$ (90:10:1, 85:15:1, 80:20:2, 70:30:3 and 50:40:10; each $250 \mathrm{~mL})$ to give subfraction $B_{7}(150 \mathrm{mg})$ which was further purified by $\mathrm{C}_{18^{-}}$ medium pressure liquid chromatography $\left(\mathrm{C}_{18}\right.$-MPLC, $\left.43 \mathrm{~g}\right)$ eluting with stepwise $\mathrm{H}_{2} \mathrm{O}-$ $\mathrm{MeOH}$ gradient (10 to $60 \% \mathrm{MeOH}$ with increasing 5\%, each $100 \mathrm{~mL}$ ) to obtain 5 (15 $\mathrm{mg})$ and 3 (23 mg). Fraction C (811 mg) was separated by $\mathrm{C}_{18}$-MPLC (130 g, 0-65\% $\mathrm{MeOH} / \mathrm{H}_{2} \mathrm{O}$, with increasing $5 \%$, each $\left.150 \mathrm{~mL}\right)$ to afford $4(12 \mathrm{mg}), \mathbf{1}(30 \mathrm{mg})$ and 3 (40 mg). Compound 2 (5 mg) was purified from fr. D (43 mg) by $\mathrm{SiO}_{2}(10 \mathrm{~g}) \mathrm{CC}$ $\left(\mathrm{CHCl}_{3}-\mathrm{MeOH}-\mathrm{H}_{2} \mathrm{O}, 95: 5: 0.5,90: 10: 1\right.$ and 85:15:1, each $\left.100 \mathrm{~mL}\right)$. Fr. F (72 mg) was chromatographed by $\mathrm{C}_{18}$-MPLC (43 g, 5-60\% MeOH/ $\mathrm{H}_{2} \mathrm{O}$, with increasing 5\%, each $100 \mathrm{~mL})$ and yielded compounds $\mathbf{1 0}(13 \mathrm{mg})$ and $\mathbf{9}(6 \mathrm{mg})$. Purification of fraction $\mathrm{H}$ (50 mg) by Sephadex LH-20 (20 g) CC (MeOH, $200 \mathrm{~mL})$ gave 8 (2 mg). Similarly, fraction I (100 mg) was applied on a Sephadex LH-20 (20 g) column (MeOH, $200 \mathrm{~mL})$ 
to obtain $6(2 \mathrm{mg})$ and $7(3 \mathrm{mg})$. The $\mathrm{CHCl}_{3}$ extract $(3.25 \mathrm{~g})$ was fractionated over a $\mathrm{SiO}_{2}(90 \mathrm{~g})$ column ( $n$-hexane-acetone, 90:10 to 10:90 with increasing 10\% of acetone, each $200 \mathrm{~mL})$ to give nine fractions, 1-9. Fraction $3(164 \mathrm{mg})$ was applied onto a $\mathrm{SiO}_{2}$ (20 g) column ( $n$-hexane-acetone, 90:10 and 85:15, each $100 \mathrm{~mL})$ to yield $\mathbf{1 1}(3 \mathrm{mg})$. The fatty acid mixture (12, $4 \mathrm{mg}$ ) was obtained from fraction 4 (77 $\mathrm{mg}$ ) by using Sephadex LH-20 (20 g) CC (MeOH, $200 \mathrm{~mL})$.

GC-MS analysis of 12 and the $\mathrm{CHCl}_{3}$ subextract. In order to analyze the FA composition of $\mathbf{1 2}$ and the $\mathrm{CHCl}_{3}$ extract, the total FAs were converted to fatty acid methyl esters (FAME) with methanolic $\mathrm{HCl}$ followed by column chromatography on $\mathrm{Si}$ gel eluting with hexane/ether (9:1). The total FAMEs were analyzed qualitatively and quantitatively by GC-MS by comparing the mass spectra of the FA methyl esters with those in the literature (NIST/EPA/NIH Mass Spectral Library) and comparing their equivalent chain length (ECL) values with known commercial standards (Sigma). The double-bonds and methyl-branching in these compounds were determined by pyrrolidide derivatization following the preparation procedure. The FAME were analyzed by electron ionization using GC-MS (Agilent 5975C MS ChemStation coupled to an Agilent 7890A GC) at $70 \mathrm{eV}$ equipped with a $30 \mathrm{~m}$ x $0.25 \mathrm{~mm}$ special performance capillary column (HP-5MS). The GC temperature program was: $130{ }^{\circ} \mathrm{C}$ for $1 \mathrm{~min}$, increased at a rate of $3{ }^{\circ} \mathrm{C} / \mathrm{min}$ to $270^{\circ} \mathrm{C}$, and maintained for $30 \mathrm{~min}$ at $270{ }^{\circ} \mathrm{C}$.

In vitro assay for Plasmodium falciparum. In vitro activity against erythrocytic stages of $P$. falciparum was determined by a modified $\left[{ }^{3} \mathrm{H}\right]$-hypoxanthine incorporation assay, using the chloroquine- and pyrimethamine-resistant $\mathrm{K} 1$ strain and the standard drug 
chloroquine. Briefly, parasite cultures incubated in RPMI 1640 medium with 5\% Albumax (without hypoxanthine) were exposed to serial drug dilutions in microtiter plates. After $48 \mathrm{~h}$ of incubation at $37^{\circ} \mathrm{C}$ in a reduced oxygen atmosphere, $0.5 \mu \mathrm{Ci}{ }^{3} \mathrm{H}$ hypoxanthine was added to each well. Cultures were incubated for a further $24 \mathrm{~h}$ before they were harvested onto glass-fiber filters and washed with distilled water. The radioactivity was counted using a Betaplate ${ }^{\mathrm{TM}}$ liquid scintillation counter (Wallac, Zurich, Switzerland). The results were recorded as counts per minute (CPM) per well at each drug concentration and expressed as percentage of the untreated controls. $\mathrm{IC}_{50}$ values were calculated from the sigmoidal inhibition curves using Microsoft Excel.

In vitro assay for Trypanosoma brucei rhodesiense. T. b. rhodesiense, STIB 900 strain, and the standard drug, melarsoprol, were used for the assay. This stock was isolated in 1982 from a human patient in Tanzania and after several mouse passages cloned and adapted to axenic culture conditions. Minimum Essential Medium (50 $\mu \mathrm{l})$ supplemented with $25 \mathrm{mM}$ HEPES, 1g/l additional glucose, 1\% MEM non-essential amino acids (100x), $0.2 \mathrm{mM}$ 2-mercaptoethanol, $1 \mathrm{mM}$ Na-pyruvate and $15 \%$ heat inactivated horse serum was added to each well of a 96-well microtiter plate. Serial drug dilutions of seven 3 -fold dilution steps covering a range from 90 to $0.123 \mu \mathrm{g} / \mathrm{ml}$ were prepared. Then $10^{4}$ bloodstream forms of $T$. $b$. rhodesiense STIB 900 in $50 \mu 1$ was added to each well and the plate incubated at $37{ }^{\circ} \mathrm{C}$ under a $5 \% \mathrm{CO}_{2}$ atmosphere for 72 h. $10 \mu \mathrm{l}$ Alamar Blue (resazurin, $12.5 \mathrm{mg}$ in $100 \mathrm{ml}$ double-distilled water) was then added to each well and incubation continued for a further $2-4 \mathrm{~h}$. Then the plates were read with a Spectramax Gemini XS microplate fluorometer (Molecular Devices Cooperation, Sunnyvale, CA, USA) using an excitation wavelength of $536 \mathrm{~nm}$ and an 
emission wavelength of $588 \mathrm{~nm}$. Data were analyzed using the microplate reader software Softmax Pro (Molecular Devices Cooperation, Sunnyvale, CA, USA).

In vitro assay for Trypanosoma cruzi. Rat skeletal myoblasts (L-6 cells) were seeded in 96-well microtitre plates at 2000 cells/well in $100 \mu \mathrm{L}$ RPMI 1640 medium with $10 \%$ FBS and $2 \mathrm{mM}$ l-glutamine. After $24 \mathrm{~h}$ the medium was removed and replaced by $100 \mu \mathrm{l}$ per well containing 5000 trypomastigote forms of $T$. cruzi Tulahuen strain C2C4 containing the $\beta$-galactosidase (Lac Z) gene. After $48 \mathrm{~h}$, the medium was removed from the wells and replaced by $100 \mu \mathrm{l}$ fresh medium with or without a serial drug dilution of seven 3-fold dilution steps covering a range from 90 to $0.123 \mu \mathrm{g} / \mathrm{ml}$. After $96 \mathrm{~h}$ of incubation the plates were inspected under an inverted microscope to assure growth of the controls and sterility. Then the substrate CPRG/Nonidet $(50 \mu \mathrm{l})$ was added to all wells. A color reaction developed within 2-6 h and could be read photometrically at 540 nm. Data were transferred into the graphic programme Softmax Pro (Molecular Devices), which calculated $\mathrm{IC}_{50}$ values. Benznidazole was the standard drug used.

In vitro assay for Leishmania donovani. Amastigotes of L. donovani strain MHOM/ET/67/L82 were grown in axenic culture at $37{ }^{\circ} \mathrm{C}$ in $\mathrm{SM}$ medium at $\mathrm{pH} 5.4$ supplemented with $10 \%$ heat-inactivated fetal bovine serum under an atmosphere of $5 \%$ $\mathrm{CO}_{2}$ in air. One hundred microlitres of culture medium with $10^{5}$ amastigotes from axenic culture with or without a serial drug dilution were seeded in 96-well microtitre plates. Serial drug dilutions covering a range from 90 to $0.123 \mu \mathrm{g} / \mathrm{ml}$ were prepared. After $72 \mathrm{~h}$ of incubation the plates were inspected under an inverted microscope to assure growth of the controls and sterile conditions. Alamar Blue $(10 \mu \mathrm{l} ; 12.5 \mathrm{mg}$ 
resazurin dissolved in $100 \mathrm{ml}$ distilled water) were then added to each well and the plates incubated for another $2 \mathrm{~h}$. Then the plates were read with a Spectramax Gemini XS microplate fluorometer using an excitation wavelength of $536 \mathrm{~nm}$ and an emission wavelength of $588 \mathrm{~nm}$. Data were analyzed using the software Softmax Pro (Molecular Devices Cooperation, Sunnyvale, CA, USA). Decrease of fluorescence (= inhibition) was expressed as percentage of the fluorescence of control cultures and plotted against the drug concentrations. From the sigmoidal inhibition curves the $\mathrm{IC}_{50}$ values were calculated. Miltefosine was used as a reference drug.

In vitro assay for cytotoxicity. Assays were performed in 96-well microtiter plates, each well containing $100 \mu$ l of RPMI 1640 medium supplemented with $1 \%$ L-glutamine $(200 \mathrm{mM})$ and $10 \%$ fetal bovine serum, and $4 \times 10^{4} \mathrm{~L}^{-6}$ cells (a primary cell line derived from rat skeletal myoblasts Serial drug dilutions of seven 3-fold dilution steps covering a range from 90 to $0.123 \mu \mathrm{g} / \mathrm{ml}$ were prepared. After $72 \mathrm{~h}$ of incubation the plates were inspected under an inverted microscope to assure growth of the controls and sterile conditions. Alamar Blue $(10 \mu \mathrm{l}, 12.5 \mathrm{mg}$ resazurin dissolved in $100 \mathrm{ml}$ double-distilled water) was then added to each well and the plates incubated for another $2 \mathrm{~h}$. Then the plates were read with a Spectramax Gemini XS microplate fluorometer using an excitation wavelength of $536 \mathrm{~nm}$ and an emission wavelength of $588 \mathrm{~nm}$. Data were analysed using the microplate reader software Softmax Pro. Podophyllotoxin was the standard drug used. 


\section{RESULTS AND DISCUSSION}

The crude $\mathrm{MeOH}$ extract of $M$. arvense showed in vitro trypanocidal and leishmanicidal activity (Table 1 ), without any toxicity towards the mammalian cells $\left(\mathrm{IC}_{50}\right.$ values $>90$ $\mu \mathrm{g} / \mathrm{ml}$ ) and was selected for in-depth chemical investigations. The crude $\mathrm{MeOH}$ extract was partitioned between $\mathrm{CHCl}_{3}$ and $\mathrm{H}_{2} \mathrm{O}$, and each subextract was submitted to the same panel of antiprotozoal and cytotoxic activity screening. As activity was detected in both extracts, each subextract was individually further purified through an activityguided isolation process. The $\mathrm{H}_{2} \mathrm{O}$ subextract yielded ten compounds, whose chemical structures were identified as iridoid glycosides aucubin (1), melampyroside (2) (Chaudhuri et al., 1981), mussaenoside (3) (El-Naggar and Beal, 1980), mussaenosidic acid (4), 8-epi-loganin (5) (Boros and Stermitz 1990), flavonoids apigenin (6), luteolin (7), luteolin 7-O- $\beta$-glucopyranoside (8) (Markham and Chari, 1982), a lignan glycoside, dehydrodiconiferyl alcohol 9-O- $\beta$-glucopyranoside (9) (Arens et al., 1985), an aromatic acid, benzoic acid (10) by comparison of their spectroscopic data (1D and 2D NMR, ESIMS and $\left.[\alpha]_{D}\right)$ with those published in the literature. As displayed in Table 1, the $\mathrm{CHCl}_{3}$ subextract was more active against all parasitic protozoa than the $\mathrm{H}_{2} \mathrm{O}$ extract. The highest bioactivity was tracked to fractions 3 and 4 obtained by a $\mathrm{SiO}_{2}$ column chromatography of the $\mathrm{CHCl}_{3}$ extract. Fraction 3 yielded the common phytosterol, $\beta$ sitosterol (11) whose structure was elucidated by comparison with published data (Kojima et al., 1990). Fraction 4 yielded a subfraction (12), which appeared to be a fatty acid mixture by ${ }^{1} \mathrm{H}$ NMR, and its exact composition was identified by GC-MS after methylation (Table 2). Only seven fatty acids (FAs) were detected in 12, with palmitic acid (16:0) and linolenic acid (18:3) being the most major ones (both at $37 \%$ relative abundance). These results prompted us to elucidate the fatty acid composition of the 
$\mathrm{CHCl}_{3}$ subextract as well. The $\mathrm{CHCl}_{3}$ extract was almost a 1:1 mixture of saturated $(45.1-48.6 \%)$ and unsaturated $(54.9-51.7 \%)$ fatty acids.

Table 1 shows the antiprotozoal activity and cytotoxic potential of all Melampyrum arvense extracts, subextracts and the metabolites isolated from them. All purified compounds, but $\mathbf{3}$ (mussaenoside), which was inactive in all assays, exhibited moderate trypanocidal activities against $T . b$. rhodesiense. Luteolin (7) appeared to be most potent trypanocidal compound with an $\mathrm{IC}_{50}$ value of $3.8 \mu \mathrm{g} / \mathrm{ml}$ and was followed by apigenin $\left(6, \mathrm{IC}_{50}\right.$ of $\left.14.0 \mu \mathrm{g} / \mathrm{ml}\right)$. Luteolin $7-O-\beta$-glucopyranoside $(\mathbf{8})$ had some trypanocidal activity ( $\mathrm{IC}_{50}$ of $24.1 \mu \mathrm{g} / \mathrm{ml}$ ) as well. Among the non-flavonoidal compounds, 8-epi-loganin (5) and the fatty acid mixture (12) exhibited the highest activity $\left(\mathrm{IC}_{50} \mathrm{~s} 17.1\right.$ and $\left.22.1 \mu \mathrm{g} / \mathrm{ml}\right)$. Only the two non-glycosidic flavones, apigenin (6) and luteolin (7), as well as $\beta$-sitosterol (11) and 12 exhibited some weak growth inhibitory effect against the American trypanosome, T. cruzi $\left(\mathrm{IC}_{50}\right.$ values of 31.9, 17.0, 35.4 and $24.2 \mu \mathrm{g} / \mathrm{ml}$, respectively). With the exception of the iridoid glycosides $\mathbf{1}$ and $\mathbf{3}$, all compounds also exerted leishmanicidal effects. The flavonoids showed the highest activity with luteolin (7) being the most potent $\left(\mathrm{IC}_{50}\right.$ of $\left.3.0 \mu \mathrm{g} / \mathrm{ml}\right)$. Apigenin $(6)$ and luteolin 7-O- $\beta$-glucopyranoside $(8)$ appeared to be equipotent $\left(\mathrm{IC}_{50}\right.$ values of 7.5 and $7.0 \mu \mathrm{g} / \mathrm{ml}$ ). The components of the $\mathrm{CHCl}_{3}$ extract, i.e. the fatty acid mixture (12) and phytosterol (11) also showed weak antileishmanial activities ( $\mathrm{IC}_{50}$ values of 10 and 27.8 $\mu \mathrm{g} / \mathrm{ml})$. All iridoids (1-5), plus the compounds $\mathbf{9}$ and $\mathbf{1 0}$ failed to arrest the growth of drug-resistant $P$. falciparum cultures at the highest test concentrations $(20 \mu \mathrm{g} / \mathrm{ml})$. The flavonoids 6-8 and both 11-12 however showed significant antiplasmodial effects $\left(\mathrm{IC}_{50}\right.$ values of $15.5,4.2,2.9,3.6$ and $4.9 \mu \mathrm{g} / \mathrm{ml})$, with luteolin $7-O$ - $\beta$-glucopyranoside (8) 
being the most active one. Among all compounds investigated, only compounds 6-7 and 11-12 displayed some moderate cytotoxicity towards mammalian cells $\left(\mathrm{IC}_{50}\right.$ values of 57.5, 16.2, 49.8 and $40.9 \mu \mathrm{g} / \mathrm{ml}$, respectively).

In conclusion, this is the first detailed phytochemical study on Turkish $M$. arvense and the first report of the antiprotozoal effect of a member of the genus Melampyrum and its constituents. In comparison to the reference compounds used in the assays, the biological activity of the Melampyrum isolates are low. However, their low toxicity may still render them promising lead compounds for future studies. Among the isolated compounds, the lignan glycoside dehydrodiconiferyl alcohol 9-O- $\beta$ glucopyranoside (9), benzoic acid (10) and the common phytosterol, $\beta$-sitosterol (11) are being reported for the first time from the genus Melampyrum.

\section{Acknowledgements}

The authors thank Dr. Galip Akaydin (Hacettepe University, Department of Biology Education, Ankara, Turkey) for authentification of the plant material. M. Cartagena thanks the NIH-RISE program for a graduate fellowship.

\section{REFERENCES}

Arens H, Fischer H, Leyck S, Römer A, Ulbrich B. 1985. Antiinflammatory compounds from Plagiorhegma dubium cell culture. Planta Med 51: 52-56.

Bonomo RA, Salata RA. 2007. American trypanosomiasis (Chagas disease; Trypanosoma cruzi). In Nelson Textbook of Pediatrics, Kleigman RM, Behrman RE, Jensen HB, Stanton BF, (eds). Elsevier Inc: Philadelphia, 1474-1477. 
Boros CA, Stermitz FR. 1990. Iridoids. An updated review Part I. J Nat Prod 53: 10551147.

Chaudhuri RK, Salama O, Sticher O. 1981. Iridoid and aryl glucosides from Globularia nudicalus and Globularia nana. Helv Chim Acta 64: 2401-2404.

Damtoft S, Hansen SB, Jacobsen B, Jensen SR, Nielsen BJ. 1984. Iridoid glucosides from Melampyrum. Phytochemistry 23: 2387-2389.

El-Naggar LJ, Beal JL. 1980. Iridoids. A review. J Nat Prod 43: 649-776.

Galkin A, Jokela J, Wahlsten M, Tammela P, Sivonen K, Vuorela P. 2009. Discovering protein kinase $\mathrm{C}$ active plants growing in Finland utilizing automated bioassay combined to LC/MS. Nat Prod Commun 4: 139-142.

Hedge IC. 1978. Melampyrum L. In Flora of Turkey and East Aegean Islands, Volume 6, Davis PH (ed). University Press: Edinburgh, 755-756.

Kirmizibekmez H, Perozzo R, Brun R, Linden A, Rüedi P, Dönmez AA, Çalıs I, Tasdemir D. 2004. Inhibiting activities of the secondary metabolites of Phlomis brunneogaleata against parasitic protozoa and plasmodial enoyl-ACP reductase, acrucial enzyme in fatty acid biosynthesis. Planta Med 70: 711-717.

Kojima H, Sato N, Hatano A, Ogura H. 1990. Sterol glucosides from Prunella vulgaris. Phytochemistry 29: 2351-2355.

Krause PJ. 2007. Malaria (Plasmodium). In Nelson Textbook of Pediatrics, Kleigman RM, Behrman RE, Jensen HB, Stanton BF, (eds). Elsevier Inc: Philadelphia, $1477-1485$.

Markham KR, Chari VM. 1982. Carbon-13 NMR Spectroscopy of Flavonoids. In The Flavonoids: Advances in Research, Harborne JB, Mabry TJ. (eds). Chapman and Hall: London, 19-132. 
Mishra BB, Kale RR, Singh RK, Tiwari, VK. 2009. Alkaloids: Future prospective to combat leishmaniasis. Fitoterapia 80: 81-90.

Rocha LG, Almeida JRGS, Macedo RO, Barbosa-Filho JM. 2005. A review of natural products with antileishmanial activity. Phytomedicine 12: 514-535.

Stajner D, Popovic BM, Boza P, Kapor A. 2009. Antioxidant capacity of Melampyrum barbatum - weed and medicinal plant. Phytother Res 23: 1006-1010.

Tasdemir D, Güner ND, Perozzo R, Brun R, Dönmez AA, Çalıs I, Rüedi P. 2005. Antiprotozoal and plasmodial FabI enzyme inhibiting metabolites of Scrophularia lepidota roots. Phytochemistry 66: 355-362.

World Health Organisation. 2006. Neglected tropical diseases, hidden successes, emerging webortunities page. Available at http://whqlibdoc.who.int/hq/2006/WHO_CDS_NTD_2006.2_eng.pdf . 2006. 
Table 1. Table 1: Trypanocidal, leishmanicidal, antiplasmodial and cytotoxic activities of the extracts of $M$. arvense and its metabolites.

\begin{tabular}{c|c|c|c|c|c}
\hline $\begin{array}{c}\text { Extract/ } \\
\text { Compound }\end{array}$ & $\begin{array}{c}T . b . \\
\text { rhodesiense }\end{array}$ & $\begin{array}{c}T . \\
\text { cruzi }\end{array}$ & $\begin{array}{c}L . \\
\text { donovani }\end{array}$ & $\begin{array}{c}P . \\
\text { falciparum }\end{array}$ & $\begin{array}{c}\text { Cytotoxicity } \\
\text { (L6 cells) }\end{array}$ \\
\hline $\begin{array}{c}\text { Standard } \\
\mathrm{MeOH} \text { extract } \mathrm{CHCl}_{3} \text { extract }\end{array}$ & $0.003^{\mathrm{a}}$ & $0.359^{\mathrm{b}}$ & $0.2^{\mathrm{c}}$ & $0.056^{\mathrm{d}}$ & $0.004^{\mathrm{e}}$ \\
$\mathrm{H}_{2} \mathrm{O}$ extract & 8.8 & $>90$ & 41.4 & $>20$ & $>90$ \\
\hline $\mathbf{1}$ & 29.5 & 67.5 & 16.3 & 8.3 & 89.7 \\
$\mathbf{2}$ & 66.6 & $>90$ & 50.9 & $>20$ & $>90$ \\
$\mathbf{3}$ & 56.6 & $>90$ & $>90$ & $>20$ & $>90$ \\
$\mathbf{4}$ & $>90$ & $>90$ & 52.7 & $>20$ & $>90$ \\
$\mathbf{5}$ & 58.3 & $>90$ & 890 & $>20$ & $>90$ \\
$\mathbf{6}$ & 17.1 & $>90$ & 41.1 & $>20$ & $>90$ \\
$\mathbf{7}$ & 14.0 & 31.9 & $\mathbf{7 . 5}$ & 15.5 & $>90$ \\
$\mathbf{8}$ & $\mathbf{3 . 8}$ & 17.0 & $\mathbf{3 . 0}$ & $\mathbf{4 . 2}$ & 16.2 \\
$\mathbf{9}$ & 24.1 & $>90$ & 7.0 & $\mathbf{2 . 9}$ & $>90$ \\
$\mathbf{1 0}$ & 60.8 & $>90$ & 68.8 & $>20$ & $>90$ \\
$\mathbf{1 1}$ & 60.8 & $>90$ & 71.5 & $>20$ & $>90$ \\
$\mathbf{1 2}$ & 86.1 & 35.4 & 27.8 & $\mathbf{3 . 6}$ & 49.8 \\
\hline
\end{tabular}

The in vitro $\mathrm{IC}_{50}$ values represent the average of at least two independent assays (the variation is $\max .20 \%$ ). All $\mathrm{IC}_{50}$ values are in $\mu \mathrm{g} / \mathrm{ml}$. Standard compounds: ${ }^{\mathrm{a}}$ melarsoprol, ${ }^{\mathrm{b}}$ benznidazole, ${ }^{\mathrm{c}}$ miltefosine, ${ }^{\mathrm{d}}$ chloroquine, ${ }^{\mathrm{e}}$ podophyllotoxin.

Table 2 Fatty acid composition of the fatty acid mixture (12) and the $\mathrm{CHCl}_{3}$ extract

\begin{tabular}{c|c|c}
\hline Fatty acid & $\mathbf{1 2}$ & $\begin{array}{c}\mathbf{C H C l}_{\mathbf{3}} \text { extract } \\
\text { Weight percent (\%) }\end{array}$ \\
\hline $\mathrm{n}-14: 0$ & Weight percent $(\%)$ & 2.1 \\
n-16:0 & $\mathbf{3 7 . 0}$ & $\mathbf{3 7 . 4}$ \\
$\mathrm{n}-17: 0$ & 0.4 & 1.0 \\
$\mathrm{n}-18: 0$ & 3.5 & 6.8 \\
$18: 2(\mathrm{n}-6)$ & 17.9 & 13.3 \\
$\mathbf{1 8 : 3 ( n - 3 )}$ & $\mathbf{3 7 . 0}$ & $\mathbf{3 8 . 4}$ \\
$\mathrm{n}-20: 0$ & 0.4 & 1.0 \\
\hline
\end{tabular}

